\title{
The hologenome concept of evolution after 10 years
}

\author{
Eugene Rosenberg ${ }^{*}$ and llana Zilber-Rosenberg
}

\begin{abstract}
The holobiont (host with its endocellular and extracellular microbiome) can function as a distinct biological entity, an additional organismal level to the ones previously considered, on which natural selection operates. The holobiont can function as a whole: anatomically, metabolically, immunologically, developmentally, and during evolution. Consideration of the holobiont with its hologenome as an independent level of selection in evolution has led to a better understanding of underappreciated modes of genetic variation and evolution. The hologenome is comprised of two complimentary parts: host and microbiome genomes. Changes in either genome can result in variations that can be selected for or against. The host genome is highly conserved, and genetic changes within it occur slowly, whereas the microbiome genome is dynamic and can change rapidly in response to the environment by increasing or reducing particular microbes, by acquisition of novel microbes, by horizontal gene transfer, and by mutation. Recent experiments showing that microbiota can play an initial role in speciation have been suggested as an additional mode of enhancing evolution. Some of the genetic variations can be transferred to offspring by a variety of mechanisms. Strain-specific DNA analysis has shown that at least some of the microbiota can be maintained across hundreds of thousands of host generations, implying the existence of a microbial core. We argue that rapid changes in the microbiome genome could allow holobionts to adapt and survive under changing environmental conditions thus providing the time necessary for the host genome to adapt and evolve. As Darwin wrote, "It is not the strongest of the species that survives but the most adaptable".
\end{abstract}

\section{Background}

Ten years ago, we introduced the hologenome concept, which considers the holobiont with its hologenome as an independent level of selection in evolution $[1,2]$. During the last few years, the hologenome concept of evolution has received considerable support and legitimate criticism, both of which have enriched the concept and led to a better understanding of what constitutes an organism, and how it evolves.

Regarding definitions, the term holobiont, first introduced by Margulis in 1991 [3], now refers to an animal or plant host together with all associated microorganisms living on or in it, exosymbionts and endosymbionts, respectively. The microbiome refers to all of the microbes associated with an animal or a plant [4]. The term microbiota preceded the term microbiome and by some is considered synonymous to it. In this paper, we refer to microbiota as being the microbes associated with an animal or plant, but not necessarily the entire community of microbes. The union of all the genes in the holobiont, i.e., all the genes in the microbiome plus the genes of the host, constitutes the hologenome $[1,2]$. The definition of a species for bacteria is controversial [5]. The most widely used bacterial species definition is a group of strains showing over $97 \%$ of $16 \mathrm{~S}$ rDNA gene-sequence identity [6].

The hologenome concept of evolution was, and still is, based on accumulated findings, from which we have extracted four basic principles:

1. All animals and plants harbor abundant and diverse microbiota and are thus considered holobionts.

2. The host with its microbiome, the holobiont, functions generally as a distinct biological entity anatomically, metabolically, immunologically, during development and in evolution. (An entity is defined as "an independent thing; that which contains in itself the conditions essential to individuality; that which forms of itself a complete whole.")

\footnotetext{
* Correspondence: eros@post.tau.ac.il

Department of Molecular Microbiology and Biotechnology, Tel Aviv University, Ramat Aviv, Israel
} 
3. A significant fraction of the microbiome genome together with the host genome is transmitted from one generation to the next and thus can propagate unique properties of the holobiont.

4. Genetic variation in the hologenome can be brought about by changes in the host genome as well as by changes in the microbiome genome. Since the microbiome genome can adjust to environmental dynamics more rapidly and by more processes than the host genome, it can play a fundamental role in the adaptation and evolution of the holobiont.

The hologenome concept considers all holobionts to exist on a spectrum from extreme symbiosis (obligatory) to a looser state of symbiosis. The endosymbionts with their host are usually an example of an extreme case of mutual metabolic and genetic adaptation with clear vertical transmission. Humans with their exosymbionts, however, are an example of a much more complex and seemingly looser symbiosis and mode of transmission; however, in both cases, the fitness (and in many cases survival) of most of the holobionts tested to date depends on the mutual interactions between all of its participants and on reasonably accurate transmission of the microbiota.

In this review, based on recent experimental and theoretical research, we discuss the current status of each of the four principles of the hologenome concept, their pros and cons, and thereby derive a fuller picture of the evolution of holobionts with their hologenomes.

\section{All animals and plants are holobionts}

The initial generality that all natural animals and plants contain abundant and diverse microbiotas has now been substantiated by analyses of numerous organisms (Table 1 ). However, as will be discussed below, the complexity and dynamics of microbiomes are only beginning to be appreciated.

The last few years have witnessed calls for major national and international efforts to characterize holobiont microbiomes [7, 8]. Knowledge about microbiomes has come primarily from studies on bacteria of the human and ruminant gut, but many more hundreds have been examined to date. From the published information, several generalizations have emerged that enable better understanding of what determines abundance and diversity and, as a result, what determines the relationship between the microbiome and its host.

\section{Quantitative considerations}

The human gut contains approximately $4 \times 10^{13}$ bacteria, similar to the total number of human cells in the body [9]. Because of the large diversity of bacterial species, the gut microbiome contains ca. 9 million unique protein-coding genes or 400 times more bacterial genes than human genes
Table 1 Numbers of bacterial species associated with animals and plants: examples

\begin{tabular}{|c|c|c|}
\hline Host & $\begin{array}{l}\text { Number of } \\
\text { bacterial species }\end{array}$ & Reference \\
\hline \multicolumn{3}{|l|}{ Invertebrates } \\
\hline Drosophila & 209 & Wong et al. [183] \\
\hline Marine sponge & 2996 & Schmitt et al. [184] \\
\hline Coral & 2050 & Ainsworth et al. [185] \\
\hline Honey bee & 336 & Moran et al. [186] \\
\hline Termite gut & 800 & He et al. [187] \\
\hline Nemotode C. elegans & 87 & Dirksen et al. [188] \\
\hline Butterfly. H. erato & 45 & Hammer et al. [189] \\
\hline \multicolumn{3}{|l|}{ Vertebrates } \\
\hline Human gut & 5700 & Nam et al. [190] \\
\hline Human skin & 1000 & Ying et al. [191] \\
\hline Bovine rumen & 5271 & Jami and Mizrahi [192] \\
\hline Great ape gut & 8914 & Ochman et al. [124] \\
\hline Cottonmouth snake & 503 & Colston et al. [193] \\
\hline Marine iguana & 896 & Hong et al. [194] \\
\hline Folivorous flying bird & 580 & Godoy-Vitorino et al. [195] \\
\hline Panda gut & 781 & Xue et al. [196] \\
\hline \multicolumn{3}{|l|}{ Plants } \\
\hline Rice & & Edwards et al. [197] \\
\hline Alga Ulva australis & 642 & Burke et al. [198] \\
\hline Carnivorous plant & 1000 & Koopman et al. [199] \\
\hline Arabidopsis & 8000 & Bai et al. [200] \\
\hline Phyllosphere & 87 & Bulgarelli et al. [78] \\
\hline Oak rhizosphere & 5619 & Mendes et al. [201] \\
\hline
\end{tabular}

[10]. It is important to realize that the bacterial count of the different bacterial species can differ by several orders of magnitude. In some cases, as few as 40 abundant bacterial species accounts for ca. $75 \%$ of the human gut microbiome [11]. However, bacterial species that are present at less than $4 \times 10^{7}$ copies $(0.00001 \%$ of the total) cannot be detected by current methods. Such relatively rare bacterial species should not be ignored since they have the potential to amplify under different conditions and play a role in adaptation and evolution of the holobiont. Clearly, analyses of the taxonomic diversity associated with the human microbiome will continue to be an area of great importance.

The gut microbiome also contains abundant and diverse viruses [12] and fungi [13], but they have not been studied extensively.

Individual variation: core and conserved function High-throughput sequencing has demonstrated that although the bacterial species composition within the human gut is unique to each person, microbiomes of 
different individuals are closer to each other than to microbiomes of other primates [14]. These data suggest that there is something common (a core) to the human microbiome. Part of the Human Microbiome Project (HMP) has provided an opportunity to examine and better define what constitutes the taxonomic core within and across body habitats and individuals [15]. Shapira [16] has emphasized the differences between conserved core microbiota and flexible, environmentally driven microbiota with regard to their maintenance and contributions to host adaptation. However, attempts to identify "core" bacterial species in the gut microbiome have yielded only a few common species. Nonetheless, as discussed above, the presence or absence of a bacterial species depends on technical limits of detection. Methods developed to detect rare species may reveal that there are many more common species than currently considered and that individual variation may be the result of quantitative rather than qualitative differences that are caused by a different diet or some other environmental factor.

An alternative explanation is possible. Although human gut microbiomes vary between individuals in taxonomic composition, the biological functions they perform are surprisingly invariable between different people. Humans harbor phylogenetically distinct gut communities that can carry out the same functions $[17,18]$. This means that there is considerable metabolic redundancy, genes, or isogenes for the same function being distributed across many species, so that a healthy gut microbiome can be assembled in many ways [19]. This idea was expressed in 2009 by Turnbaugh et al. [20] and lately in an article by Doolittle and Booth [21], titled: "It's the song, not the singer....". This is consistent with the hologenome concept, which considers all of the genes of a holobiont, not necessarily specific species.

\section{Variation with time and environmental conditions}

The composition of human gut microbiomes and their corresponding hologenomes change with age, diet, medication, and many other factors. Gut microbiomes of newborns are dominated by facultative anaerobes such as the Proteobacteria, after which the diversity of strict anaerobes within the Firmicutes and Bacteroidetes phyla increases towards an adult-like profile by approximately 1 year of age [22]. Throughout this early developmental stage, microbial composition is shaped by mode of delivery [23], infant diet [24], antibiotic treatment [25], and exposure to environmental factors, such as furry pets [26]. During most of adult years, the microbiome seems to be more or less stable [27]. The gut microbiome in older people ( $>65$ years), however, is extremely variable between individuals and differs from the microbiome of younger adults [28]. Microbiomes of people in long-stay care centers are less diverse than that of community dwellers and are correlated with low fiber diets and increased frailty [29].

Food, food additives, and essentially any material that is put in the mouth affects the gut microbiota at all ages. Both long-term [30] and short-term [31] diet influences the human gut microbiota. An "animal-based diet," rich in meats, eggs, and cheeses increases the abundance of bile-tolerant microorganisms (Alistipes, Bilophila, and Bacteroides), whereas a "plant-based diet," composed of grains, legumes, fruits, and vegetables, increases the levels of Firmicutes that metabolize dietary plant polysaccharides. Not only macronutrients, but also other components that are consumed affect the microbiome, such as red wine [32], tea and coffee [33], chocolate [34], food emulsifiers [35], artificial sweeteners [36], and, of course, antibiotics [37]. Also, the microbiome is affected by other factors such as, physical activity [38] and illnesses, e.g., cancer [39] and diabetes [40].

\section{Host genetics affects the microbiome}

In addition to environmental factors, host genetics plays a role in the acquisition, maintenance and stability of gut microbiota [41-43]. The three components, environment, host genetics, and microbiome, interact to maintain homeostasis in the gut. The disruption of this stability by modifying one or more of these three interacting components may trigger the development of diseases. It has been shown that a single host gene can have a large effect on the diversity and population structure of the gut microbiota. Most of the genes shown to have an impact on the composition of the gut microbiome are components of the immune system.

\section{Endosymbionts and exosymbionts}

Although exosymbionts are present in all animals and plants, it is well documented that non-pathogenic endosymbiosis is common only among plants and invertebrates (e.g., insects and corals). To the best of our knowledge, endosymbionts are not present in vertebrates. Invertebrates and plants have developed homeostatic interactions with the endosymbionts to benefit both. Moreover, they have developed specific immunological systems that participate in maintaining and controlling this important relationship $[44,45]$. The close proximity of endosymbionts to host nuclei may enhance exchange of genetic material, as discussed in the section on "Genetic variation and evolution of holobionts." In vertebrates, the more complex immune system appears to limit penetration of microorganisms into organs and cells $[46,47]$, while enabling a homeostatic and often beneficial relationship to develop with the exosymbionts.

\section{Interactive fitness in holobionts}

Since the original presentation of the hologenome concept of evolution [2], a large number of studies have 
demonstrated the beneficial interactions between microbiomes and their hosts, leading to a better-adapted holobiont. In obligatory symbioses, the interdependence between host and microbiome is absolute. In many other holobionts, the measure of interdependence of the participants differs. Though it is not always easy to demonstrate the effect of the microbiome on survival and reproduction with facultative symbionts, it has been demonstrated in a number of systems. Stunted growth, shortened lifespan, and deteriorating reproduction were demonstrated in water fleas [48], termites [49], and firebugs and cotton strainers [50]. However, a large volume of data has demonstrated that microbiomes participate in many functions within the holobiont, as will be described immediately, though the extent of their requirement is not always clear.

\section{Protection against pathogens}

In general, germfree (GF) animals are more sensitive to infection by pathogens than conventional (CV) animals [51]. Following oral infection, the numbers of Listeria monocytogenes, a pathogenic bacteria, were 10,000-fold higher in the small intestine of GF mice compared to CV mice [52]. Staphylococcus aureus infection is prevented by resident Corynebacterium species [53]. Recently acquired symbiotic bacteria protect corals against the bleaching pathogen Vibrio shiloi [54]. Production of antibiotics is a common mechanism by which resident bacteria protect the holobiont against pathogens [55]. One of the strongest arguments for the role of bacteria in combatting infectious disease is the successful treatment of patients, suffering from severe diarrhea caused by Clostridium difficile infection, with fecal transplants from healthy donors [56]. Bacteria have also been shown to protect plants against infectious diseases by inhibiting the phytopathogen and by inducing systemic resistance $[57,58]$.

\section{Provision of nutrients}

An important general fitness contribution of microbiomes to their hosts is carrying out metabolic processes that the animal or plant cannot carry out by themselves [59]. There are many examples: nitrogen fixation in legumes [60], cellulose degradation in ruminants [61], termites [62] and cockroaches [63], essential amino acid synthesis in insects [64], photosynthesis by microalgae in corals, mollusks and sponges [65], and oxidation of inorganic compounds [66] and hydrocarbons in deep-sea invertebrates [67].

In humans, gut bacteria have been shown to perform several beneficial biochemical reactions that cannot be carried out by the host. For example: (i) production of metabolites from dietary components, such as the conversion of dietary fiber to the short-chain fatty acids, acetate, propionate. and butyrate [68]; (ii) modification of metabolites that are produced by the host, such as primary bile acids that are converted to secondary bile acids, thus assisting in bile acid recycling [69]; (iii) de novo synthesis of compounds, such as the important microbial immune modulator polysaccharide A, produced by the common gut bacterium Bacteroides fragilis [70]; (iv) synthesis of vitamins. Certain gut bacteria can produce vitamin $K$ as well as most of the water-soluble $B$ vitamins [71].

\section{Fat storage and obesity}

Not only is the composition of the gut microbiome of obese and lean individuals different [72], but more significantly, fecal bacteria transferred from obese humans to germ-free mice caused a greater increase in body weight than transplants from lean humans [73], suggesting that the microbiome in combination with diet and genetic factors causes obesity. Although bacteria that contribute to obesity could be considered harmful, under certain conditions they are beneficial. During the third trimester of pregnancy, these so-called "obese bacteria" become abundant and induce metabolic changes that promote energy storage in fat tissue that in turn encourages growth of the fetus [74] and milk production in the mother. Also, during our evolution, food insecurity was a frequent occurrence, and the ability to store energy in the form of fat was probably advantageous for survival.

\section{Development and behavior}

It is has been known for many years that certain microbial symbionts (once termed primary symbionts) interact with their hosts to benefit the holobionts: Rhizobia strains cooperate with legume plants to produce root nodules that perform nitrogen fixation [75]. Vibrio fisheri triggers the formation of the light organ in squid, where luminescence occurs to help the squid avoid predation [76]. Intracellular algae of the genus Symbiodinium carry out photosynthesis that provides nutrients to their host coral [77]. In recent years, it has been shown that codevelopment of the microbiome with animals and plants is not limited to primary symbionts. In plants, microbes associated with root tips acquire nutrients from plant secretions and in turn produce indole acetic acid that stimulates root elongation and lateral root formation [78]. In vertebrates, the gut microbiome promotes the development of the immune system and body organs [79]. Exposure to microorganisms educates the immune system, induces innate and adaptive immunity [80, 81], and initiates memory $\mathrm{B}$ and $\mathrm{T}$ cells that are essential to combat various pathogens. In addition, the gut microbiome encourages also the development of bone mass [82] and blood vessels in the intestinal wall [83].

Hydra is an evolutionarily ancient multicellular organism which has been used as a model system in developmental biology. Recently, it has been shown that Hydra microbiota plays an essential function in reproduction [84] and 
influences the spontaneous contractions, likely by modulating the pacemaker activity movement [85].

Bacteria in the mammalian gut also modulate brain development and behavior, including anxiety and mood disorders [86]. Data from experiments performed in rodents with altered intestinal microbiota, whether germ-free mice, or conventionally raised animals treated with probiotics and/or antibiotics, all indicate that rodent behavioral responses are impacted when the bacterial status of the gut is manipulated [87]. Microbial gut-brain signaling is bidirectional. The circuitry of neurons, hormones, and chemical neurotransmitters allows messages to be transmitted between the brain and the gut. For example, the rate at which food is being moved and how much mucus is lining the gut-both of which can be controlled by the brain-have a direct impact on the environmental conditions the microbiota experiences. On the other hand, the gut microbiota influences the body's level of the potent neurotransmitter serotonin, which promotes in addition to gut functions also feelings of happiness and peacefulness [88].

\section{Microbiomes warm their hosts}

Recently, we suggested that provision of heat is an underappreciated general contribution of microbiomes to holobionts [89]. Microbiomes produce heat as a by-product of the enzymatic catabolism of substrates and synthesis of cell material. It was reported that bacteria have specific rates of heat production of ca. One hundred sixty-eight milliwatts per gram [90, 91]. Based on these findings, it can be calculated [92] that about $70 \%$ of human body heat production at rest is the result of bacterial metabolism in the gut.

Consistent with the concept that microbes warm their hosts are reports that treatment of rabbits [93] and rodents [94] with antibiotics lowered their body temperature. Heat output by gut microbiota may also help explain the observation that germ-free mice had $40 \%$ less total body fat than conventionally raised mice, even if their caloric intake was $29 \%$ higher [95]. The warming effect of microbiomes has also been reported in plants [96]. Heat produced by the sugar catabolism of yeast populations inhabiting floral nectar increased the temperature of the nectar and modified the within-flower thermal microenvironment.

Though the significance of heat production by microbiomes has scarcely been studied, its contribution may have far-reaching implications. It may help warm-blooded animals avoid hypothermia, and in cold-blooded animals, it can raise their body temperature.

\section{Transmission}

For holobionts to be considered units of selection in evolution, both the host and microbiome genomes, i.e., the hologenome, are expected to be transferred between generations. The conservative mechanism for transmission of host DNA is well understood and need not be discussed here. Transmission of the microbiome also occurs, but with a variety of mechanisms and with less precision than the host genome. This section will describe the different modes of microbiome transmission and the evidence that it is transferred for many generations. Table 2 summarizes examples of the main modes of microbiome transmission.

Vegetative reproduction occurs in many plants and some animals. In plants, this type of asexual reproduction can involve adventitious roots, corms, tubers, bulbs, and leaf plantlets. Vegetative reproduction in animals includes budding and fragmentation. As a consequence of vegetative reproduction, the microbiome is transferred vertically to offspring. Transmission of microbiota via oocytes and seeds is another example of vertical transmission. Endosymbionts, such as Buchnera in aphids [97] and Wolbachia in many insects [98], are transferred vertically via oocytes. Vertical transmission in plants has been shown to occur via seeds in many species of herbaceous flowering plants [99], suggesting that this may be a widespread phenomenon.

In vegetarian or omnivore animals, eating mother's feces (coprophagy) is practiced by many young animals, thereby obtaining the bacteria required to properly digest complex polysaccharides found in their diet. Koalas use a special adaptation of coprophagy [100]. From birth to about 6 months, the joey remains in the pouch, relying only on the mothers' milk. At the end of this period, the mother produces a liquid form of feces, referred to as pap, which the joey ingests over several days. The pap contains the appropriate gut microbiota for digestion of eucalyptus leaves, enabling eventual weaning from the mother. In the termite hindgut-microbiota symbiosis, feces of adult termites are fed to newly hatched juveniles by workers in the colony [101]. Many insects lay eggs in their feces, which are consumed by larval offspring upon hatching [102]. Depending on the extent that the feces mix with microbes in the environment, transmission by coprophagy can be vertical (e.g., koala) or both vertical and horizontal.

Although it has been reported that the human fetus contains bacteria [103, 104], a recent study using very careful methodologies [105] did not find microbial DNA in the human placenta, suggesting that the human placenta and fetus are sterile. Also, the ability to raise Cesareanderived germ-free animals in the laboratory argues against a microbiota colonizing the placenta and fetus [106].

Colonization of the newborn human gut occurs initially via inoculation with maternal vaginal and fecal microbes when the baby transits the birth channel (vertical transmission). Some of these pioneers are facultative anaerobic bacteria, such as Escherichia coli, which convert the newborn aerobic gut to anaerobiosis, allowing growth of strict anaerobes [107].

Breastfeeding has been shown to provide an additional route of maternal vertical microbial transmission in 
Table 2 Examples of modes of symbiont transmission

\begin{tabular}{ll}
\hline Mode of transmission & Examples \\
\hline Vegetative reproduction (vertical) & Plants, worms [99], corals [202], echinoderms [203] \\
Via oocytes (vertical) & Drosophila/Wolbachia [98], aphid/Buchnera [97], sponge [204], herbs/fungi [205] \\
Coprophagy (vertical and horizontal) & Many animals: termites [101], rabbits [206], koala [100], insects [102] \\
Mother's milk (vertical) & Mammals [108-110] \\
Physical contact starting at birth (Vertical and horizontal) & Most animals: fish [207], amphibians [208], mammals [209] \\
Horizontal & Grasses/endophytes [120], squid/Vibrio fischeri [119] \\
\hline
\end{tabular}

Adapted from Roughgarden et al. [182]. Vertical transmission is defined as the movement of microbiota from parent to offspring without mixing with microbes in the environment

humans [108-110], nonhuman primates [111], and cows [112]. Human milk contains ca. $10^{5}$ bacteria per $\mathrm{ml}$, composed of hundreds of species [113]. Analyses of the DNA of several bacterial strains isolated from mothers' milk demonstrated that they were identical to those found in the offspring [114], providing reinforcement for vertical transmission. Mother's milk is also a continuous source of modified oligosaccharides that support the growth of the major group of these bacteria, Bifidobacterium species, but are not digestible by the infant [115]. The Bifidobacterium species contain unique genetic loci responsible for vigorous growth on these oligosaccharides [116]. These findings suggest a remarkable co-evolution between the symbiotic bacteria and their human host enabling gut colonization that benefits both. The Bifidobacteria is provided with environmental gains such as food and protection. The infant benefits by being protected against pathogens, by diverse carbohydrate breakdown and cross-feeding activities of the Bifidobacteria with other microbes in the gut, thereby enhancing shortchain fatty acid synthesis, and also by specific molecular interactions of the Bifidobacteria with infant gut components $[117,118]$.

Transmission of microbiota from parent to offspring can also occur horizontally, i.e., via the environment. A well-studied example is responsible for maintaining the squid light organ-Vibrio fischeri symbiosis [119]. The female host lays clutches of hundreds of fertilized eggs, which hatch almost synchronously at dusk. In parallel, adult squid releases large amounts of $V$. fischeri into the water at dawn every day. The growing embryos develop an immature light organ, which is free of bacteria but has pores leading to separate epithial-lined crypts. These crypts become colonized by the released $V$. fischeri. Furthermore, the developing squid provides a niche in which only $V$. fischeri that emits light is able to maintain a stable association. However, there is no evidence that the $V$. fischeri acquired by the offspring came from one of its parents. It could have come from a different squid in the same environment. Nevertheless, in this horizontal transmission, the holobiont is reconstituted. The reconstruction has to be accurate; otherwise, it does not function
[119]. Another example of a reliable horizontal transmission of microbiota is in different kinds of grasses, where the microbes are transferred from one plant to other plants of the same species [120].

As has been discussed above, vertical and horizontal transmissions represent the extreme cases. In most situations, transmission occurs via a mixed mode. Obligatory symbiosis usually relies on vertical transmission while a looser form of symbiosis can be based on a less precise transmission. It is important to note that vertical transmission enables an accurate transfer of the hologenome and ensures continuation of the mutual metabolic activities within the holobiont. Horizontal transfer of microbiota, on the other hand, increases the possibility of the holobiont acquiring novel genetic material. As will be discussed in the next section, acquisition of novel microbes from the environment is one mechanism for gene variation and evolution of holobionts.

Given that several mechanisms exist for the transmission of microbiomes, what is the evidence that microbiomes are actually transferred with fidelity for multiple generations and over evolutionary time scales? One of the first indications that human microbes can be transmitted for many generations came from a detailed analysis of the sequence diversity of DNA isolated from Helicobacter pylori present in different geographic human populations [121]. The fact that the distinct sequence remains for centuries in offspring of an individual that has migrated to a different geographical location argues for accurate vertical transmission and has led to the use of $H$. pylori in resolving details of human migration [122]. Another early experiment demonstrating that microbiotas can be maintained for many holobiont generations involved two closely related species of Hydra that differed greatly in their bacterial microbiome [123]. Even though these Hydra were kept in the same laboratory environment for $>30$ years, they maintained their characteristic microbiomes. The authors point out that the microbiotas could have been maintained by vertical transmission or by horizontal selective and differential attachment sites on their membranes.

Long-term transmission of microbiota was studied by comparing the $16 \mathrm{~S}$ ribosomal gene sequences of bacteria 
associated with great apes, including humans [124]. The host species phylogenies based on the composition of these microbial communities was completely congruent with the known evolutionary relationships of the hosts. The authors concluded that over evolutionary timescales, the composition of the gut microbiota among great ape species is phylogenetically conserved and has diverged in a manner consistent with vertical inheritance.

However, Moran and Sloan [125] correctly pointed out that vertical transmission of bacterial species, based on $16 \mathrm{~S}$ rRNA gene sequences, cannot be used to prove coevolution because it is possible that over evolutionary timescales other strains of the same species (97\% identity in $16 \mathrm{~S}$ rDNA sequence) could be acquired from the environment. To overcome this problem, Sanders et al. [126] developed an elegant analytical tool, beta-diversity clustering, which distinguishes between shared evolutionary history and environmental filtering. The basic idea is that in the case where co-diversification is the primary factor leading to similarity among microbiomes, recent host speciation should be reflected by recent symbiont speciation. By contrast, in the case where host environment selects for different microbes, the most recent common ancestor of a pair of microbes in the two hosts may far pre-date the last common ancestor of the hosts. Using beta-diversity clustering on the previously published great ape data [124] led to the conclusion that apes acquire species-specific microbiota largely horizontally, while retaining a proportion of vertically transmitted microbes over longer timescales. Application of this test to turtle ants (genus Cephalotes) indicated a high degree of partner fidelity in the ant microbiota, suggesting that vertical transmission of the entire community could play an important role in the evolution and maintenance of the association [126].

Moeller et al. [127] used rapidly evolving gyrB gene sequences in fecal samples from humans, from wild chimpanzees, and from wild bonobos to profile strain diversity within the gut microbiomes of great apes. Unlike $16 \mathrm{~S}$ rDNA sequencing, this technology allows inference of the phylogenies of closely related bacterial lineages, thereby enabling tests for co-speciation between gut bacteria and the Hominidae. The analysis revealed that strains of the common gut bacteria, Bacteroidaceae and Bifidobacteriaceae, have been maintained exclusively within host lineages across hundreds of thousands of host generations. Divergence times of these co-speciating gut bacteria are congruent with those of hominids, indicating that nuclear, mitochondrial, and gut bacterial genomes, i.e., hologenomes, diversified in concert during hominid evolution. Gut bacteria therefore are not simply acquired from the environment, but have co-evolved for millions of years with hominids to participate in their development, especially in shaping their immune systems.
Using the honeybee as a model system, with relatively few microbial species though with similarities to mammalian microbiomes, Kwong and Moran [128] have concluded: "Together, these bacteria form a specialized microbial community that has co-evolved and diversified with its bee hosts over millions of years." The authors mentioned the importance of sociality to the reliable transmission of microbiota in these species and others.

Phylosymbiosis was proposed to describe the ecoevolutionary pattern, whereby microbiomes parallel the phylogeny of related host species [129]. In support of this hypothesis, it was observed that (i) intraspecific microbiota variation is consistently less than interspecific microbiota variation; (ii) congruence analyses of each group's complete phylogeny and microbiota dendrogram reveal significant degrees of phylosymbiosis, irrespective of host clade age or taxonomy. This is consistent with selection of host-microbiota interactions driving phylosymbiosis; (iii) there are survival and performance reductions when interspecific microbiota transplants are conducted between closely related and divergent host species pairs.

Co-evolution of animal hosts with their microbiome is made possible by creating a homeostatic relationship between the host and the microbiome. This relationship must be based on prevention of pathological effects of the microbiome in addition to control over the composition of microbial consortia together with immune tolerance towards the microorganisms. It has also to include adaptation of the microorganisms to the specific conditions, in or on the host, and a functional integration of the microorganisms within the holobiont.

It is difficult to imagine such co-adaptation that does not involve a core of microorganisms that fulfills these kinds of homeostatic requirements and that is albeit observed individual species variation (see also discussion above: individual variation: core and conserved function).

\section{Genetic variation and evolution of holobionts}

In our original presentation of the hologenome concept of evolution [2], we suggested that genetic variation and evolution occur not only via changes in host genomes but also via changes in microbiome genomes. In addition to the well-recognized modes of genetic variation in all organisms, mutation, sexual recombination, chromosome rearrangement and epigenetic changes, we considered three underappreciated modes of genetic variation that are characteristic of microbiomes in holobionts: (i) amplification or reduction of the number of a specific microbial group, (ii) acquisition of novel microbes, and (iii) horizontal gene transfer (HGT).

\section{Amplification or reduction}

Amplification/reduction refers to the increase or decrease of one group (e.g., species) of symbionts relative 
to others, which can occur rapidly when conditions change. The holobiont is a dynamic entity with certain microorganisms multiplying and others decreasing in number as a function of local conditions within the holobiont. An increase in the number of a particular microbe is equivalent to amplification of a whole set of genes. Considering the large amount of genetic information encoded in the diverse microbial population of holobionts, often more than in the host genome [10], microbial amplification/reduction can be a powerful mechanism for contributing to adaptation, development, and evolution of holobionts. Reported examples of environmental factors that lead to changes in symbiont populations and thereby to variations in hologenomes include nutrient availability [130-134], artificial sweeteners [36, 135], food emulsifiers [136], disease states [137-140], $\mathrm{pH}$ [141], temperature [142], and of course antibiotics [143-145]. Prebiotics, food ingredients that induce the growth or activity of beneficial microorganisms [146], is an applied example of the amplification principle [147].

Since genetic variation by amplification is driven by the environment, it has a Lamarckian aspect to it, as discussed by us in a previous paper [148]. As will be reviewed in the next section, amplification is a crucial step in genetic variation and evolution by acquisition of novel microbes. For a pioneer microbe to become established in its host it must multiply.

\section{Acquisition of novel microbes from the environment}

Microbes were on this planet for 2.1 billion years before there were any animals or plants. During this time, they evolved enormous biochemical diversity and split into two domains, Bacteria and Archaea. The first eukaryote was probably formed by the acquisition of bacteria to eventually form mitochondria [149] and chloroplasts [150] and possibly by the uptake of an Archaea by Bacteria to form the nucleus [151]. Uptake of microbes into multicellular organisms continued to provide genetic variation for holobionts throughout evolution. Many of the beneficial interactive fitness traits of holobionts discussed above fit into this category.

Animals and plants come into random contact with billions of microorganisms during their lifetime, via air, water and interaction with organic and inorganic surfaces. Occasionally some of these microbes will find a niche and under appropriate conditions amplify in the host and affect the phenotype of the holobiont. Unlike mutation, which causes small changes in existing genomes, acquisition of a microbe introduces hundreds of new genes into the holobiont. Rather than reinvent the wheel, animals and plants can acquire pre-evolved genetic information in the form of microbes. It is likely that after the microbe is acquired, mutations and selection occur in the microbe and host to optimize the interaction.
An example of a major evolutionary event that was driven by the acquisition of bacteria is the ability of many animals to use plant material, in the form of cellulose and other complex polysaccharides, as nutrients. However, animal genomes do not contain the information for synthesizing enzymes for degrading cellulose. Instead, animals such as termites, cockroaches, and ruminants rely on cellulolytic microorganisms that are present in their digestive tract. These microbes anaerobically convert cellulose to fatty acids that are the major source of carbon and energy for their host animal [134]. How did they gain access to these specialized microbes? It is likely that the evolution of termite and cockroach hindgut microbiotas occurred by the gradual process of internalizing from the environment microorganisms that digest plant litter. Instead of plant cellulose being broken down in the soil prior to ingestion, it "rots" in the hindgut after consumption [152]. It has also been suggested that cockroaches acquired cellulolytic microbes by eating the dung of dinosaurs [153], which are known to have been hindgut fermenters [154].

There are many other examples of important evolutionary events that were driven by the acquisition of microbes by animals and plants. Such examples include acquisition of zooxanthellae by corals and other marine invertebrates, which formed photosynthetic animals and led to the construction of coral reefs [155], acquisition of diverse chemosynthetic bacteria by deep sea animals, which allowed for life in the absence of light [156], acquisition of anaerobic bacteria by the gut of ants, which supported herbivory [157], and acquisition of nitrogenfixing bacteria by legumes, which permitted plant growth under limiting nitrogen conditions [158].

\section{Horizontal gene transfer}

Another important mode of genetic variation in holobionts, referred to as horizontal gene transfer (HGT) or lateral gene transfer, involves the transfer of groups of genes between bacteria of different taxa and from microbiomes to their hosts. HGT is generally associated with gene transfer between different bacteria, but can also take place from microorganisms to animals and plants and the other way around. The intimate contact between microbes and host genomes in holobionts would promote HGTs [159]. On average, bacteria in the human gut contain a minimum of 49 observed horizontally acquired genes [160]. It has been suggested that nutritional adaptation is one of the key selective pressures on the microbiome in the mammalian gut and that HGT processes contribute to that adaptation [161].

An interesting example of evolution of humans by HGT between bacteria is the ability of Japanese to break down agar (an abundant ingredient in their diet) since they have a bacterium in their gut that contains genes 
that code for the porphyranases that degrade the polysaccharide agarose of agar. Westerners lack this bacterium in their gut and therefore cannot digest agar. The group of genes coding for agarose digestion was driven into a resident gut bacterium by HGT from a marine bacterium that was present on raw seaweed [162]. Although HGT usually occurs between bacteria in the same ecological niche, apparently the marine bacterium was present in the gut long enough to have some of its genes transferred to a resident gut bacterium. Furthermore, the bacteria with the transferred genes spread throughout the Japanese population by vertical and horizontal transmission [163].

Until 2010, only a few examples of HGT from microbes to animals were recognized: Wolbachia genes to the chromosomes of their insect hosts [164], bacterial and fungal genes into the telomere region of rotifers [165], fungal genes to aphids [166], and cellulose genes from bacteria to nematodes [167]. However, an examination of the recent availability of a large number of highquality genomes has led to the conclusion that HGT in animals and plants typically results in tens or even hundreds of active foreign genes [168]. Analysis of the 13.7megabase genome of the extremophile red alga Galdieria sulphuraria revealed that $5 \%$ of its protein-coding genes were acquired by HGT from bacteria and archaea [169]. Examination of the genomes of 12 Drosophila species showed on average 40 foreign genes that had been horizontally transferred from bacteria and fungi [170]. When the Drosophila species were placed on a phylogenetic tree, there was a correspondence between the number of HGT events and the length of each branch, suggesting that HGT has occurred throughout Drosophila evolution and is likely to be ongoing. This paper also pointed out that HGT events were more frequent in invertebrates than in vertebrates, an observation that may be explained by the closer proximity between invertebrate endosymbiont (intracellular) and host genetic material.

In humans, 145 genes (not present in other primates) were attributed to HGT [170]. These genes are distributed throughout the genome and play a variety of roles, such as amino-acid metabolism (two genes), macromolecule modifications (15 genes), lipid metabolism (13 genes), antioxidant activities (5 genes), and innate immune response ( 7 genes). Most of the 145 genes identified in the study came from bacteria, but some originated from viruses and yeasts. Analysis of the moss Physcomitrella patens identified 128 genes found in land plants but absent from algae [171]. These genes were acquired by HGT from prokaryotes, fungi or viruses. Many of these genes are involved in some essential or plantspecific activities such as xylem formation, plant defense, nitrogen recycling, and the biosynthesis of starch, polyamines, hormones, and glutathione.
A key event in the evolution of placental mammals, including humans, was the acquisition by HGT, from a retrovirus, of the gene coding for the protein syncytin [172]. Initially, the function of syncytin was to allow retroviruses to fuse host cells so that viruses could move from one cell to another. Now, syncytin is necessary for the development of the placental syncytium, the essential part of the mother-fetus barrier. Knockout of syncytin genes in genetically modified mice provided evidence for their absolute requirement for placenta development and embryo survival [173]. Similarly, retroviral-derived molecules appear to have played a crucial function in the generation of the progesterone-sensitive uterine decidual cell, allowing nutrient provision to the developing embryo [174]. These data indicate that the integration of viral DNA into a host genome played a primary role in a major evolutionary leap by enabling growth and maturation of the fetus in placental mammals. In general, it is clear that introduction of genes by HGT into eukaryote genomes has been a major force propelling genetic variation and evolution.

\section{Role of microbiomes in speciation}

Experiments on speciation in animals provide further support for the hologenome concept of evolution. In 1989, Dodd reported that splitting a homogenous population of Drosophila and propagating some of the flies on a molasses medium and the others on a starch medium resulted in mating preference [175]. The "molasses flies" preferred to mate with other molasses flies, and "starch flies" preferred to mate with other starch flies. However, the data could not be explained by existing evolutionary theory because the mating preference was too rapid, especially since there was no selection for mating preference. The experiment was considered important because mating preference is an early event in the emergence of new species [176].

Consideration of the hologenome concept led us to hypothesize that changes in the microbiome were responsible for the diet-induced mating preference. To test this hypothesis, flies were treated with antibiotics. The antibiotics abolished the mating preference, suggesting that fly bacteria were responsible for the phenomenon [177]. This was confirmed when it was shown that infecting antibiotic-treated flies with pure cultures of Lactobacillus plantarum isolated from starch flies reestablished mating preference. Furthermore, analytical data showed that L. plantarum changed the levels of cuticular hydrocarbon sex pheromones emitted by the flies [178]. In general, volatile metabolites produced by animal microbiomes may play an important role in mate-choice recognition and selection [179].

The microbiome can also play a role in post-zygotic reproductive success. When recently diverged wasp species 
were artificially cross-bred, the hybrids died during the larval stage. However, if the wasps were treated with antibiotics prior to mating, the hybrids survived [180]. The authors concluded: "In this animal complex, the gut microbiome and host genome represent a co-adapted hologenome that breaks down during hybridization, promoting hybrid lethality and assisting speciation." Similar results were obtained in two house mice subspecies, suggesting that microbiomes could also contribute to reproductive isolation in vertebrates [181].

\section{Conclusions}

There is now considerable evidence supporting the hypothesis that holobionts with their hologenomes can be considered levels of selection in evolution. The first principle we posited, all animals and plants harbor abundant and diverse microbiota, is now supported by abundant data. The second principle, the holobiont functions as a distinct biological entity, and interactions between microbiomes and their hosts affect the fitness of holobionts, has also been largely substantiated. However, the extent to which the microbiota contributes to holobiont fitness and survival varies enormously. The third principle, where genomes of both hosts and a significant fraction of microbiomes are transferred between generations, is the most contentious. Although there is now evidence that in some animals, microbiota can be maintained by vertical transmission for thousands of generations, it is not possible to generalize on these findings. Finally, regarding the fourth principle, molecular studies have demonstrated that genetic variation and the evolution of holobionts involve acquisition of novel microbes and HGT of microbial genes into host chromosomes.

As the evolutionary biologist Elizabeth Lloyd recently wrote [182], "the holobiont with its hologenome is a level of selection since it is an "interactor", a "replicator", a "manifestor of adaptation" and a "beneficiary" of the selection process." Evolution proceeds by both cooperation and competition, working in parallel. An initial mathematical model of holobiont evolution has been reported [182]. Future microbiome research should be expanded to include a larger number of different animal and plant holobiont species and the role of protists and viruses in holobionts.

\section{Acknowledgements}

This review was compiled following an International Conference on Holobionts held in Paris (Natural History National Museum) April 19-21, 2017. We thank the organizers of this meeting.

\section{Authors' contributions}

Both authors prepared the manuscript equally. Both authors read and approved the final manuscript.

\section{Competing interests}

The authors declare that they have no competing interests.

\section{Publisher's Note}

Springer Nature remains neutral with regard to jurisdictional claims in published maps and institutional affiliations.

Received: 22 September 2017 Accepted: 5 April 2018

Published online: 25 April 2018

\section{References}

1. Rosenberg E, Koren $\mathrm{O}$, Reshef $\mathrm{L}$, Efrony $\mathrm{R}$, Zilber-Rosenberg I. The role of microorganisms in coral health, disease and evolution. Nat Rev Microbiol. 2007:5:355-62.

2. Zilber-Rosenberg I, Rosenberg E. Role of microorganisms in the evolution of animals and plants: the hologenome theory of evolution. FEMS Microbiol Rev. 2008;32:723-35.

3. Margulis L. Symbiosis as a source of evolutionary innovation: speciation and morphogenesis. In: Margulis L, Fester R, editors. Symbiogenesis and Symbionticism. Cambridge: MIT Press; 1991. p. 1-14.

4. Lederberg J, McCray AT. "Ome Sweet Omics"—a genealogical treasury of words. Scientist. 2001;15:8.

5. Chan J, Halachev MR, Loman NJ, Constantinidou C, Pallen MJ. Defining bacterial species in the genomic era: insights from the genus Acinetobacter. BMC Microbiol. 2012;12:302. https://doi.org/10.1186/1471-2180-12-302.

6. Wayne LG, Brenner DJ, Colwell RR, Grimont PAD, Kandler O, Krichevsky MI, Moore LH, Moore WEC, Murray RGE, Stackebrandt E, Starr MP, Truper HG. Report of the ad hoc committee on reconciliation of approaches to bacterial systematics. Int J Syst Evol Microbiol. 1987;37:463-4.

7. OSTP (The White House Office of Science and Technology Policy) Fact Sheet: Announcing The National Microbiome Initiative. 2016. United States Government. https://www.whitehouse.gov/sites/whitehouse.gov/files/documents/OSTP\%20 National\%20Microbiome\%20Initiative\%20Fact\%20Sheet.pdf.

8. Alivisatos AP, Blaser MJ, Brodie EL, et al. Unified microbiome initiative consortium: a unified initiative to harness Earth's microbiomes. Science. 2015;350:507-8.

9. Sender R, Fuchs S, Milo R. Revised estimates for the number of human and bacteria cells in the body. PLoS Biol. 2016;14(8):e1002533. https://doi.org/10. 1371/journal.pbio.1002533.

10. Yang X, Xie L, Li Y, Wei C. More than $9,000,000$ unique genes in human gut bacterial community: estimating gene numbers inside a human body. PLoS One. 2009;4(6):e6074. https://doi.org/10.1371/journal.pone.0006074

11. Faith $\mathrm{JJ}$, Guruge $\mathrm{JL}$, Charbonneau M, et al. The long-term stability of the human gut microbiota. Science. 2013;341:1237439. https://doi.org/10.1126/ science. 1237439.

12. Ogilvie $L A$, Jones $B V$. The human gut virome: a multifaceted majority. Front Microbiol. 2015;6:918. https://doi.org/10.3389/fmicb.2015.00918.

13. Hoffmann C, Dollive S, Grunberg S, Chen J, Li H, Wu GD, et al. Archaea and fungi of the human gut microbiome: correlations with diet and bacterial residents. PLoS One. 2013;8(6):e66019. https://doi.org/10.1371/journal.pone

14. Ley RE, Lozupone CA, Hamady M, Knight R, Gordon Jl. Worlds within worlds: evolution of the vertebrate gut microbiota. Nat Rev Microbiol. 2008;6:776-88.

15. Group NHW, Peterson J, Garges S, Giovanni M, Mclnnes P, Wang L, Schloss JA, Bonazzi V, McEwen JE, Wetterstrand KA, et al. The NIH human microbiome project. Genome Res. 2009;19:2317-23.

16. Shapira M. Gut microbiotas and host evolution: scaling up symbiosis. Trends Ecol Evol. 2016;31:539-49.

17. Turnbaugh PJ, Hamady M, Yatsunenko T, Cantarel BL. Diversity, stability and resilience of the human gut microbiota. Nature. 2012;489:220-30.

18. Taxis T, Wolff S, Gregg SJ, Minton NO, Zhang C, et al. The players may change but the game remains: network analyses of ruminal microbiomes suggest taxonomic differences mask functional similarity. Nucl Acids Res. 2015;2:9600-12.

19. Bradley PH, Katherine S, Pollard KS. Proteobacteria explain significant functional variability in the human gut microbiome. Microbiome. 2017;5:36. https://doi.org/10.1186/s40168-017-0244.

20. Turnbough PJ, Hamady M, Yatsunenko T, et al. A core gut microbiome in obese and lean twin. Nature. 2009;457:480-4.

21. Doolittle WF, Booth A. It's the song, not the singer: an exploration of holobiosis and evolutionary theory. Biol Philos. 2016; https://doi.org/10. 1007/s10539-016-9542-2.

22. Bäckhed F, Roswall J, Peng Y, Feng Q, Jia H, Kovatcheva-Datchary P, Li Y, Xia Y, Xie $H$, Zhong $H$, et al. Dynamics and stabilization of the human gut microbiome during the first year of life. Cell Host Microbe. 2015;17(5):690-703. 
23. Song SJ, Dominguez-Bello MG, Knight R. How delivery mode and feeding can shape the bacterial community in the infant gut. CMAJ. 2013;185(5): 373-3744. https://doi.org/10.1503/cmaj.130147.

24. Pop M. We are what we eat: how the diet of infants affects their gut microbiome. Genome Biol. 2012;13(4):152.

25. Yassour M, Vatanen $T$, Siljander $H$, Hämäläinen $A M$, et al. Natural history of the infant gut microbiome and impact of antibiotic treatment on bacteria strain diversity and stability. Sci Transl Med. 2016; https://doi.org/10.1126/ scitransImed.aad0917.

26. Tun HM, Konya T, Takaro TK, Brook JR, et al. Exposure to household furry pets influences the gut microbiota of infants at 3-4 months following various birth scenarios. Microbiome. 2017;5:40. https://doi.org/10.1186/s40168-017-0254.

27. Claesson MJ, Cusack S, O'Sullivan O, Greene-Diniz R, et al. Composition, variability, and temporal stability of the intestinal microbiota of the elderly. Proc Natl Acad Sci U S A. 2011;108:4586-91.

28. Zoetendal EG, Akkermans AD, De Vos W. Temperature gradient gel electrophoresis analysis of 165 rRNA from human fecal samples reveals stable and host-specific communities of active bacteria. Appl Environ Microbiol. 1998;64:3854-9.

29. Claesson MJ, Jeffery IB, Conde S, Power SE, et al. Gut microbiota composition correlates with diet and health in the elderly. Nature. 2012;488:178-84.

30. Wu GD, Chen J, Hoffmann C, Bittinger K, et al. Linking long-term dietary patterns with gut microbial enterotypes. Science. 2011;334:105-8.

31. David LA, Maurice CF, Carmody RN, Gootenberg DB, et al. Diet rapidly and reproducibly alters the human gut microbiome. Nature. 2014;505:559-63.

32. Queipo-Ortuño MI, Boto-Ordóñez M, Murri M, Gomez-Zumaquero JM, et al. Influence of red wine polyphenols and ethanol on the gut microbiota ecology and biochemical biomarkers. Am J Clin Nutr. 2012;95:1323-34

33. Zhernakova A, Kurilshikov A, Jan Bonder M, Tigchelaar EF, et al. Populationbased metagenomics analysis reveals markers for gut microbiome composition and diversity. Science. 2016;352:565-9.

34. Tzounis X, Rodriguez-Mateos A, Vulevic J, Gibson GR, Kwik-Uribe C, Spencer JP. Prebiotic evaluation of cocoa-derived flavanols in healthy humans by using a randomized, controlled, double-blind, crossover intervention study. Am J Clin Nutr. 2011;93:62-72.

35. Chassaing B, Koren O, Goodrich JK, Poole AC, et al. Dietary emulsifiers impact the mouse gut microbiota promoting colitis and metabolic syndrome. Nature. 2013;519:92-6.

36. Suez J, Korem T, Zeevi D, Zilberman-Schapira G, et al. Artificial sweeteners induce glucose intolerance by altering the gut microbiota. Nature. 2014;514:181-6.

37. Langdon A, Crook N, Dantas G. The effects of antibiotics on the microbiome throughout development and alternative approaches for therapeutic modulation. Genome Med. 2016;8(1):39. https://doi.org/10.1186/s13073.

38. Santacruz A, Marcos A, Wärnberg J, Martí A, Martin-Matillas M, Campoy C, Moreno LA, Veiga O, Redondo-Figuero C, et al. Interplay between weight loss and gut microbiota composition in overweight adolescents. Obesity. 2009;17:1906-15

39. Wang T, Cai G, Qiu Y, et al. Structural segregation of gut microbiota between colorectal cancer patients and healthy volunteers. ISME J. 2012;6:320-9.

40. Qin J, Yingrui Li Y, Cai Z, Li S, et al. A metagenome-wide association study of gut microbiota in type 2 diabetes. Nature. 2012;490:55-60.

41. Spor A, Omry Koren O, Ley R. Unravelling the effects of the environment and host genotype on the gut microbiome. Nat Rev Microbiol. 2011;9:279-90.

42. Knight R, RWeersma RK, et al. Complex host genetics influence the microbiome in inflammatory bowel disease. Genome Med. 2014;6:107.

43. Bensona AK, Kelly SA, Leggea R, Maa F, et al. Individuality in gut microbiota composition is a complex polygenic trait shaped by multiple environmental and host genetic factors. Proc Natl Acad Sci U S A. 2010;44:18933-8.

44. Login $\mathrm{FH}$, Heddi A. Insect system maintains long-term resident bacteria through a local response. J Insect Physiol. 2013;59:232-9.

45. Limpens E, van Zeijl A, Geurts R. Lipochitooligosaccharides modulate plant host immunity to enable endosymbiosis. Annu Rev Phytopathol. 2015;53:311-34.

46. McFall-Ngai M. Care for the community. Nature. 2007:445:153.

47. Cerutti A, Chen K, Chorny A. Immunoglobulin responses at the mucosal interface. Annu Rev Immunol. 2011:29:273-93.

48. Sison-Mangus MP, Mushegian AA, Ebert D. Water flies require microbiota for survival, growth and reproduction. ISME J. 2015;9:59-67.

49. Rosengaus RB, Zecher CN, Schultheis KF, et al. Disruption of the termite gut microbiota and its prolonged consequences for fitness. Appl Environ Microbiol. 2011;77:4303-12.
50. Salem H, Kreutzer E, Sudakaran S, Kaltenpoth M. Actinobacteria as essential symbionts in firebugs and cotton strainers (Hemiptera, Pyrrhocoridae). Environ Microbiol. 2013;15:1956-68.

51. Geraldine O, Canny GO, McCormick BA. Bacteria in the intestine, helpful residents or enemies from within? Infect Immun. 2008;76:3360-73.

52. Archambau C, Sismeirod O, Toedling J, Soubigoud G, et al. The intestinal microbiota interferes with the microRNA response upon oral Listeria infection. MBio. 2013;4(6):e00707-1.

53. Ramsey MM, Freire MO, Gabrilska RA, Rumbaugh KP, Lemon KP. Staphylococcus aureus shifts toward commensalism in response to Corynebacterium species. Front Microbiol. 2016; https://doi.org/10.3389/fmicb.2016.01230.

54. Mills E, Shechtman K, Loya Y, Rosenberg E. Bacteria appear to play important roles both causing and preventing the bleaching of the coral Oculina patagonica. MEPS. 2013;4:155-62.

55. Donia MS, Cimermancic $P$, Schulze CJ, Fischbach MA. A systematic analysis of biosynthetic gene clusters in the human microbiome reveals a common family of antibiotics. Cell. 2014;158:1402-1414.76.

56. Drekonja D, Reich J, Gezahegn S, Greer N, Shaukat A, MacDonald R, Rutks I, Wilt TJ. Fecal microbiota transplantation for Clostridium difficile infection: a systematic review. Ann Intern Med. 2015;162:630-8.

57. Cytryn E, Kolton M. Microbial protection against plant disease. In: Rosenberg E, Gophna U, editors. chapter 4 Beneficial microorganisms in multicellular life forms. Heidelberg: Springer; 2011.

58. Marasco R, Rolli E, Ettoumi B, Vigani G, Mapell F. A drought resistancepromoting microbiome is selected by root system under desert farming. PLoS One. 2012;7(10):e48479.79.

59. Rosenberg E, Zilber-Rosenberg I. Microbes drive evolution of animals and plants: the hologenome concept. MBio. 2016;7(2):e01395.

60. Gage DJ. Infection and invasion of roots by symbiotic, nitrogen-fixing rhizobia during nodulation of temperate legumes. Microbiol Mol Biol Rev. 2017:68:280-300.

61. Jami E, Israel A, Kotser A, Mizrahi I. Exploring the bovine rumen bacterial community from birth to adulthood. ISME J. 2013;7:1069-79.

62. Brune A. Symbiotic digestion of lignocellulose in termite guts. Nat Rev Microbiol. 2014;12:168-80.

63. Zhang J, Zhang Y, Li J, Liu M, Liu Z. Midgut transcriptome of the cockroach Periplaneta americana and its microbiota: digestion, detoxification and oxidative stress response. PLoS One. 2016:11(5):e0155254.

64. Ayayee PA, Larsen T, Sabree Z. Symbiotic essential amino acids provisioning in the American cockroach, Periplaneta americana (Linnaeus) under various dietary conditions. PeerJ. 2016;4:e2046.

65. Rumpho ME, Pelletreau KN, Moustafa A, Bhattacharya D. The making of a photosynthetic animal. J Exp Biol. 2010;214:303-11.

66. Ponnudurai R, Kleiner M, Sayavedra L, Petersen JM, et al. Metabolic and physiological interdependencies in the Bathymodiolus azoricus symbiosis. ISME J. 2017;11(2):463-77.

67. Rubin-Blum M, Antony CP, Borowski C, Sayavedra L, et al. Short-chain alkanes fuel mussel and sponge Cycloclasticus symbionts from deep-sea gas and oil seeps. Nat Microbiol. 2017;19:17093. https://doi.org/10.1038/ nmicrobiol.93.

68. Han M, Wang $C$, Liu $P$, et al. Dietary fiber gap and host gut microbiota. Protein Pept Lett. 2017;24:388-96.

69. Martinez-Augustin O, Sanchez de Medina F. Intestinal bile acid physiology and pathophysiology. World J Gastroenterol. 2008;14:5630-40.

70. Sharma S, Erickson KM, Troutman JM. Complete tetrasaccharide repeat unit biosynthesis of the immunomodulatory Bacteroides fragilis capsular polysaccharide A. ACS Chem Biol. 2017;12:92-101.

71. LeBlanc JG, Milani C, Savoy de Giori G, Sesma F, et al. Bacteria as vitamin suppliers to their host: a gut microbiota perspective. Curr Opin Biotechnol. 2013;24:160-8.

72. Ley RE, Turnbaugh PJ, Klein S, Gordon Jl. Microbial ecology: human gut microbes associated with obesity. Nature. 2006:444:1022-3.

73. Ridaura VK, Faith JJ, Rey FE, Cheng J, et al. Gut microbiota from twins discordant for obesity modulate metabolism in mice. Science. 2013:341: 1241214. https://doi.org/10.1126/science.1241214.

74. Koren O, Goodrich JK, Cullender TC, et al. Host remodeling of the gut microbiome and metabolic changes during pregnancy. Cell. 2012;150: 470-80

75. Jones KM, Kobayashi H, Davies BW, Taga ME, Walker GC. How rhizobial symbionts invade plants: the Sinorhizobium medicago model. Nat Rev Microbiol. 2007:5:619-33. 
76. McFall-Ngai MJ. Consequences of evolving with bacterial symbionts: insights from the squid-Vibrio association. Ann Rev Ecol Syst. 1999;30:235-56.

77. Baker AC. Flexibility and specificity in coral-algal symbiosis: diversity, ecology, and biogeography of Symbiodinium. Annu Rev Ecol Evol Syst. 2003;34:661-89

78. Bulgarelli D, Schlaeppi K, Spaepen S, van Themaat E, Schulze-Lefert P. Structure and functions of the bacterial microbiota of plants. Annu Rev Plant Biol. 2013;64:807-38.

79. Sommer F, Bäckhed F. The gut microbiota—masters of host development and physiology. Nat Rev Microbiol. 2013;11:227-38.

80. Thaiss CA, Zmora N, Levy M, Einav E. The microbiome and innate immunity. Nature. 2016;535:65-74.

81. Round $\mathrm{L}$, Mazmanian SK. The gut microbiome shapes intestinal immune responses during health and disease. Nat Rev Immunol. 2009;5:312-23.

82. Sjogren K, Engdahl C, Henning P, Lerner UH, Tremaroli V, Lagerquist MK, Bäckhed F, Ohlsson C. The gut microbiota regulates bone mass in mice. J Bone Miner Res. 2012;27:1357-67.

83. Schirbel A, SeanKessler S, Rieder F, West G, et al. Pro-angiogenic activity of TLRs and NLRs: a novel link between gut microbiota and intestinal angiogenesis. Gastroenterology. 2013;144:613-23.

84. Gaikwad SS, Ghaskadbi SS, Shouche YS, Ghaskadbi S. Changes in the microbial community associated with Hydra during reproduction. Matters. 2017; https://doi.org/10.19185/matters.201706000004

85. Murillo-Rincon AP, Klimovich A, Pemöller E, et al. Spontaneous body contractions are modulated by the microbiome of Hydra. Sci Rep. 2017;7: 15937. https://doi.org/10.1038/s41598-017-16191-X.

86. Heijtz RD, Wang S, Anuard F, Qian Y, Björkholm B, et al. Normal gut microbiota modulates brain development and behavior. Proc Natl Acad Sci. 2011;108:3047.

87. Foster JA, Neufeld KM. Gut-brain axis: how the microbiome influences anxiety and depression. Trends Neurosci. 2013;36:305-312.107.

88. O'Mahonya SM, Clarkea G, Borrea YE, Dinana TG, Cryana JF. Serotonin, tryptophan metabolism and the brain-gut-microbiome axis. Behav Brain Res. 2015;277:32-48.

89. Rosenberg E, Zilber-Rosenberg I. Do microbes warm their hosts? Gut Microbes. 2016;7:283-5.

90. Russell JB. Heat production by ruminal bacteria in continuous culture and its relationship to maintenance energy. J Bacteriol. 1987;168:694-701.

91. Russel JB. A re-assessment of bacterial growth efficiency: the heat production and membrane potential of Streptococcus bovis in batch and continuous culture. Arch Microbiol. 1991;155:559-65.

92. Henry CJ. Basal metabolic rate studies in humans: measurement and development of new equations. Pub Health Nutr. 2005;8:1133-52.

93. Fuller A, Mitchell D. Oral antibiotics reduce body temperature of healthy rabbits in a thermoneutral environment. J Basic Clin Physiol Pharm. 2011;10:1-14.

94. Kluger MJ, Conn CA, Franklin B, Freter R, Abrams GD. Effect of gastrointestinal flora on body temperature of rats and mice. Am J Phys. 1990;258:552-7

95. Bäckhed F, Ding H, Wang T, Hooper LV, Koh GY, Nagy A, Semenkovich CF, Gordon J. The gut microbiota as an environmental factor that regulates fat storage. Proc Natl Acad Sci U S A. 2004;101:15718-23.

96. Herrera CM, Pozo MI. Nectar yeasts warm the flowers of a winter-blooming plant. Proc Biol Sci. 2010;277:1827-34.

97. Baumann P, Lai CY, Roubakhsh D, Moran NA, Clark MA. Genetics, physiology, and evolutionary relationships of the genus Buchnera-intracellular symbionts of aphids. Annu Rev Microbiol. 1995;49:55-94.

98. Veneti Z, Clark ME, Karr TL, Savakis C, Bourtziz K. 2004. Heads or tails: hostparasite interactions in the Drosophila-Wolbachia system. Appl Environ Microbiol 2004; 70:5366-5372.

99. Fell PE. Reproductive biology of invertebrates. Asexual propagation and reproductive strategies. In: Adyodi KG, Adyodi RG, editors. Porifera. Chichester: Wiley; 1993. p. 1-44

100. Osawa R, Blanshard WH, Ocallaghan PG. Microbiological studies of the intestinal microflora of the koala, Phascolarctos cinereus. II. Pap, a special maternal feces consumed by juvenile koalas. Aust J Zool. 1993;41:611-20.

101. Brune A, Dietrich C. The gut microbiota of termites: digesting the diversity in the light of ecology and evolution. Annu Rev Microbiol. 2015;69:145-66.

102. Zimmer M, Topp W. The role of coprophagy in nutrient release from feces of phytophagous insects. Soil Biol Biochem. 2002;34:1093-9.

103. Aagaard K, Ma J, Antony KM, Ganu R, Petrosino J, Versalovic J. The placenta harbors a unique microbiome. Sci Transl Med. 2014;6:237ra65.
104. Collado MC, Rautava S, Aakko J, Isolauri E, Salminen S. Human gut colonisation may be initiated in utero by distinct microbial communities in the placenta and amniotic fluid. Sci Rep. 2016;6:23129.

105. Lauder AP, Roche AM, Sherrill-Mix S, et al. A comparison of placenta samples with contamination controls does not provide evidence for a distinct placenta microbiota. Microbiome. 2016;4:29. https://doi.org/10.1186/ s40168-016-0172-3.

106. Blaser MJ, Dominguez-Bello. The human microbiome before birth. Cell Host Microbiome. 2016;20:558-60

107. Mueller NT, Bakacs E, Combellick J, Grigoryan Z, Dominguez-Bello MG. The infant microbiome development: mom matters. Trends Mol Med. 2014:21:109-17.

108. Sakwinska O, Moine D, Delley M, Combremont $S$, et al. Microbiota in breast milk of Chinese lactating mothers. PLoS One. 2016;11(8):e0160856.

109. Fernández L, Langa S, Martína V, Maldonadoa A, et al. The human milk microbiota: origin and potential roles in health and disease. Pharmacol Res. 2013;69:1-10.

110. Jost T, Lacroix C, Braesier C, Chassard C. Assessment of bacterial diversity in breast milk using culture-dependent and culture- independent approaches. Br J Nutr. 2013;14:1-10.

111. Jin L, Hinde K, Tao L. Species diversity and relative abundance of lactic acid bacteria in the milk of rhesus monkeys (Macaca mulatta). J Med Primatol. 2011;40:52-8.

112. Addis MA, Uzzau TS, Oikonomou Bicalho GRC, Moroni P. The bovine milk microbiota: insights and perspectives from -omics studies. Mol BioSyst. 2016;19:2359-72.

113. Martín R, Lang S, Jimínez E, Marín MM, et al. Human milk is a source of lactic acid bacteria for the infant gut. J Pediatr. 2003;143:754-75.

114. Milani C, Mancabelli L, Lugli LGA, et al. Exploring vertical transmission of Bifidobacteria from mother to child. Appl Environ Microbiol. 2015;81:7078-87.

115. Sela DA, Li Y, Lerno L, Wu S, et al. An infant-associated bacterial commensal utilizes breast milk sialyloligosaccharides. J Biol Chem. 2011;286:11909-18.

116. Garrido D, Ruiz-Moyano S, Kirmiz SN, Davis JC, et al. A novel gene cluster allows preferential utilization of fucosylated milk oligosaccharides in Bifidobacterium longum subsp. Iongum SC596. Sci Rep. 2016;6:35045. https://doi.org/10.1038/srep35045.

117. Liévin V, Peiffer I, Hudault S, et al. Bifidobacterium strains from resident infant human gastrointestinal microflora exert antimicrobial activity. Gut. 2000:47:646-52.

118. Turroni F, Milani C, Duranti S, Ferrario C, et al. Bifidobacteria and the infant gut: an example of co-evolution and natural selection. Cell Mol Life Sci. 2017; https://doi.org/10.1007/s00018-017-2672-0

119. Nyholm SV, Stewart JJ, Ruby EG, et al. Recognition between symbiotic Vibrio fischeri and the haemocytes of Euprymna scolopes. Environ Microbiol. 2008; 11:483-93.

120. Tadych M, Bergen MS, White JF. Epichloë spp. associated with grasses: new insights on life cycles, dissemination and evolution. Mycologia. 2014;106: 181-201.

121. Achtman M, Azuma T, Berg DE, Ito $Y$, et al. Recombination and clonal groupings within Helicobacter pylori from different geographical regions. Mol Microbiol. 1999;32:459-70.

122. Falush D, Wirth T, Linz B, Pritchard JK, et al. Traces of human migrations in Helicobacter pylori populations. Science. 2003;299:1582-5.

123. Fraune S, Bosch TCG. Long-term maintenance of species-specific bacterial microbiota in the basal metazoan Hydra. Proc Natl Acad Sci U S A. 2007;104: 13146-51.

124. Ochman H, Worobey M, Kuo C-H, et al. Evolutionary relationships of wild hominids recapitulated by gut microbial communities. PLoS Biol. 2010;8: e1000546.

125. Moran NA, Sloan DB. The hologenome concept: helpful or hollow? PLoS Biol. 2015;13(12):e1002311.

126. Sanders JG, Powell S, Kronauer DJ, Vasconcelos HL, Frederickson ME, Pierce NE. Stability and phylogenetic correlation in gut microbiota: lessons from ants and apes. Mol Ecol. 2014;23:1268-83.

127. Moeller AH, Caro-Quintero A, Mjungu D, Georgiev AV, et al. Co-speciation of gut microbiota with hominids. Science. 2016;353:380-2.

128. Kwong WK, Moran NA. Gut microbial communities of social bees. Nat Rev Microbiol. 2016;14:374-84.

129. Brooks AW, Kohl KD, Brucker RM, van Opstal EJ, Bordenstein SR Phylosymbiosis: relationships and functional effects of microbial communities across host evolutionary history. PLoS Biol. 2016;14: e2000225. pmid:27861590 
130. De Filippo C, Cavalieria D, Di Paolab M, et al. Impact of diet in shaping gut microbiota revealed by a comparative study in children from Europe and rural Africa. Proc Natl Acad Sci U S A. 2010;107:14691-6.

131. Koenig JE, Spor A, Scalfone N, et al. Succession of microbial consortia in the developing infant gut microbiome. Proc Natl Acad Sci U S A. 2010;108: 4578-85.

132. Turnbaugh PJ, Ridaura VK, Faith JJ, Rey FE, Knight R, Gordon Jl. The effect of diet on the human gut microbiome: a metagenomic analysis in humanized gnotobiotic mice. Sci Transl Med. 2009;1:6ra14.160. Zimmermann MB, Chassard

133. Rohner F, N'Goran EK. The effects of iron fortification on the gut microbiota in African children: a randomized controlled trial in Côte d'Ivoire. Am J Clin Nutr. 2010;92:1406-15.

134. Petra L, Hold G, Flint $H$. The gut microbiota, bacterial metabolites and colorectal cancer. Nat Rev Microbiol. 2014;12:661-72.

135. Palmnäs MSA, Cowan TE, Bomhof MR, Su J, et al. Low-dose aspartame consumption differentially affects gut microbiota-host metabolic interactions in the diet-induced obese rat. PLoS One. 2014;9:e109841.

136. Chassaing B, Koren O, Goodrich J, Poole A. Dietary emulsifiers impact the mouse gut microbiota promoting colitis and metabolic syndrome. Nature. 2015;519:92-6

137. Yuna J, Roh SW, Whon TW, Jung M, et al. Insect gut bacterial diversity determined by environmental habitat, diet, developmental stage, and phylogeny of host. Appl Environ Microbiol. 2014;80:5254-64.

138. Shanahan F, Quigley EMM. Manipulation of the microbiota for treatment of IBS and IBD_challenges and controversies. Gastroenterology. 2014;146:1554-63.

139. Mouzaki M, Comelli EM, Arendt BM, Bonengelet J. Intestinal microbiota in patients with nonalcoholic fatty liver disease. Hepatology. 2013;58:120-7.

140. Shena J, Obinc MS, Zhaoa L. The gut microbiota, obesity and insulin resistance. Mol Asp Med. 2013;34:39-58.

141. Scott KP, Gratz SW, Sheridan PO, Flint HJ, Dunca SH. The influence of diet on the gut microbiota. Pharmacol Res. 2013;69:52-60.

142. Zogg GP, Zak DR, Ringelberg DB, MacDonald NW, et al. Compositional and functional shifts in microbial communities due to soil warming. Soil Sci Soc Am J. 1997;61:475-81.

143. Dethlefsen L, Relman DA. Incomplete recovery and individualized responses of the human distal gut microbiota to repeated antibiotic perturbation. PNAS. 2011;108:4554-456.

144. Panda S, Elkhader I, Casellas F, López Vivancos J, et al. Short-term effect of antibiotics on human gut microbiota. PLoS One. 2014;9:e95476.

145. Jernberg C, Löfmark S, Edlund C, Jansson JK. Long-term impacts of antibiotic exposure on the human intestinal microbiota. Microbiology. 2010;156:3216-23.

146. Hutkins RW, Krumbeck JA, Bindels LB, Cani PD, et al. Prebiotics: why definitions matter. Curr Opin Biotechnol. 2016;37:1-7.

147. Zilber-Rosenberg I, Rosenberg E. Prebiotics and probiotics within the framework of the hologenome concept. J Microb Biochem Techn. 2011; https://doi.org/10.4172/1948-5948.S1-001

148. Rosenberg E, Sharon G, Zilber-Rosenberg I. The hologenome theory of evolution: a fusion of neo-Darwinism and Lamarckism. Environ Microbiol. 2009:11:2959-62.

149. Dyall SD, Brown MT, Johnson PJ. Ancient invasions: from endosymbionts to organelles. Science. 2001:304:253-7.

150. McFadden GI, Van Dooren GG. Evolution: red algal genome affirms a common origin of all plastids. Curr Biol. 2004;14:R514-516.179.

151. Martin W. Archaebacteria (Archaea) and the origin of the eukaryotic nucleus. Curr Opin Microbiol. 2005;8:630-7.

152. Dietrich $C$, Köhler T, Brune A. The cockroach origin of the termite gut microbiota: patterns in bacterial community structure reflect major evolutionary events. Appl Environ Microbiol. 2014;80:2261-9.

153. Vršanský $P$, van de Kamp T, Azar D, Prokin A, Vidlička L, Vagovič P. Cockroaches probably cleaned up after dinosaurs. PLoS One. 2013;8(12):e80560.

154. Mackie RI. Mutualistic fermentative digestion in the gastrointestinal tract: diversity and evolution. Integr Comp Biol. 2002;42(2):319.

155. Stanley GD. Photosymbiosis and the evolution of modern coral reefs. Science. 2006;312:857-8.

156. Dubilier N, Bergin C, Lott C. Symbiotic diversity in marine animals: the art of harnessing chemosynthesis. Nat Rev Microbiol. 2008;6:725-40.

157. Russell JA, Moreau CS, Goldman-Huertas B, Mikiko Fujiwara M, et al. Bacterial gut symbionts are tightly linked with the evolution of herbivory in ants. PNAS. 2009;106:21236-41.

158. Oldroyd GED, Murray JM, Poole PS, Downie JA. The rules of engagement in the legume-rhizobial symbiosis. Annu Rev Genet. 2011;45:119-44.
159. Gao C, Ren X, Mason AS, Liu H, et al. Horizontal gene transfer in plants. Funct Integr Genomics. 2014;14:23-9.

160. Liu L, Chen X, Skogerbø G, Zhang P, et al. The human microbiome: a hot spot of microbial horizontal gene transfer. Genomics. 2012;100:265-70.

161. Sousa A, Frazão N, Ramiro RS, Gordo I. Evolution of commensal bacteria in the intestinal tract of mice. Curr Opin Microbiol. 2017;38:114-21.

162. Hehemann JH, Correc G, Barbeyron T, et al. Transfer of carbohydrate-active enzymes from marine bacteria to Japanese gut microbiota. Nature. 2010; 464:908-14.

163. Hehemann JH, Kelly AG, Pudlo NA, Martens EC, Boraston AB. Bacteria of the human gut microbiome catabolize red seaweed glycans with carbohydrateactive enzyme updates from extrinsic microbes. Proc Natl Acad Sci U S A. 2012;109:19786-91.

164. Nikoh N, Tanaka K, Shibata F, et al. Wolbachia genome integrated in an insect chromosome: evolution and fate of laterally transferred endosymbiont genes. Genome Res. 2008;18:272-80.

165. Gladyshev EA, Meselson M, Arkhipova IR. Massive horizontal gene transfer in bdelloid rotifers. Science. 2008;320:1210-3.

166. Moran NA, Jarvik T. Lateral transfer of genes from fungi underlies carotenoid production in aphids. Science. 2010;328:624-7.

167. Mitreva M, Smant G, Helder J. Role of horizontal gene transfer in the evolution of plant parasitism among nematodes. Methods Mol Biol. 2009;532:517-35.

168. Sieber KB, Bromley RE, Hotopp JCD. Lateral gene transfer between prokaryotes and eukaryotes. Exp Cell Res. 2017; https://doi.org/10.1016/j. yexcr.2017.02.009

169. Schönknecht G, Chen WH, Ternes CM, et al. Gene transfer from bacteria and archaea facilitated evolution of an extremophilic eukaryote. Science. 2013; 339:1207-10.

170. Crisp A, Boschetti C, Perry M, et al. Expression of multiple horizontally acquired genes is a hallmark of both vertebrate and invertebrate genomes. Genome Biol. 2015;16:50. https://doi.org/10.1186/s13059-015-0607-3.

171. Yue J, Hu X, Huang J. Horizontal gene transfer in the innovation and adaptation of land plants. Plant Signal Behav. 2013;8:e24130.

172. Dupressoir A, Lavialle C, Heidmann T. From ancestral infectious retroviruses to bona fide cellular genes: role of the captured syncytins in placentation. Placenta. 2012;33:663-71.

173. Lavialle C, Cornelis G, Dupressoir A, et al. Paleovirology of 'syncytins', retroviral env genes exapted for a role in placentation. Philos Trans R Soc Lond Ser B Biol Sci. 2013;368:20120507.

174. Wagner GP, Kin K, Muglia L, Pavlicev M. Evolution of mammalian pregnancy and the origin of the decidual stromal cell. Int J Dev Biol. 2014;58:117-26.

175. Dodd DMB. Reproductive isolation as a consequence of adaptive divergence in Drosophila-pseudoobscura. Evolution. 1989;43:1308-11.

176. Coyne JA, Orr HA. Speciation. Sunderland: Sinauer; 2004.

177. Sharon G, Segal D, Ringo JM, et al. Commensal bacteria play a role in mating preference of Drosophila melanogaster. Proc Natl Acad Sci U S A 2010;107:20051-6.

178. Sharon G, Segal D, Zilber-Rosenberg I, Rosenberg E. Symbiotic bacteria are responsible for diet-induced mating preference in Drosophila melanogaster, providing support for the hologenome concept of evolution. Gut Microbes. 2011:2:190-2.

179. Ezenwa VO, Williams AE. Microbes and animal olfactory communication: where do we go from here? BioEssays. 2014:36:847-54.

180. Brucker RM, Bordenstein SR. The hologenomic basis of speciation: gut bacteria cause hybrid lethality in the genus Nasonia. Science. 2013:341:667-9.

181. Wang J, Kalyan S, Steck N, et al. Analysis of intestinal microbiota in hybrid house mice reveals evolutionary divergence in a vertebrate hologenome. Nat Commun. 2015;6:6440. https://doi.org/10.1038/ncomms7440.

182. Roughgarden J, Gilbert SF, Rosenberg E, et al. Holobionts as units of selection and a model of their population dynamics and evolution. Biol Theory. 2017; https://doi.org/10.1007/s13752-017-0287-1.

183. Wong AC, Chaston JM, Douglas AE. The inconstant gut microbiota of Drosophila species revealed by 165 rRNA gene analysis. Intl Soc Microbil Ecol J. 2012;10:1922-32.

184. Schmitt S, Tsai P, Bell J, et al. Assessing the complex sponge microbiota: core, variable and species-specific bacterial communities in marine sponges. ISME J. 2012;6:564-76.

185. Ainsworth TD, Krause L, Bridge T, et al. The coral core microbiome identifies rare bacterial taxa as ubiquitous endosymbionts. ISME J. 2015;9:2261-74.

186. Moran NA, Hansen AK, Powell JE, Sabree ZL. Distinctive gut microbiota of honey bees assessed using deep sampling from individual worker 
bees. PLoS One. 2012;7(4):e36393. https://doi.org/10.1371/journal.pone. 0036393

187. He S, Ivanova N, Kirton E, et al. Comparative metagenomic and metatranscriptomic analysis of hindgut paunch microbiota in wood- and dung-feeding higher termites. PLoS One. 2013;8(4):e61126.

188. Dirksen P, Marsh SA, Braker I, Heitland N, et al. The native microbiome of the nematode Caenorhabditis elegans: gateway to a new host-microbiome model. BMC Biol. 2016;14:38.

189. Hammer TJ, McMillan WO, Fierer N. Metamorphosis of a butterfly-associated bacterial community. PLoS One. 2014;9(1):e86995. https://doi.org/10.1371/ journal.pone

190. Nam YD, Jung MJ, Roh SW, et al. Comparative analysis of Korean human gut microbiota by barcoded pyrosequencing. PLoS One. 2011;6(7):e22109. https://doi.org/10.1371/journal.pone.0022109.

191. Ying S, Zeng D-N, Chi L, Tan Y, Galzote C, Cardona C, et al. The influence of age and gender on skin-associated microbial communities in urban and rural human populations. PLoS One. 2015;10(10):e0141842. https://doi.org/ 10.1371/journal.pone.0141842

192. Jami E, Mizrahi I. Composition and similarity of bovine rumen microbiota across individual animals. PLoS One. 2012;7(3):e33306.

193. Colston TJ, Noonan BP, Jackson CR. Phylogenetic analysis of bacterial communities in different regions of the gastrointestinal tract of Agkistrodon piscivorus, the cottonmouth snake. PLoS One. 2015;10(6): e0128793. https://doi.org/10.1371/journal.pone.0128793

194. Hong PY, Wheeler E, Cann IKO, Mackie RI. Phylogenetic analysis of the fecal microbial community in herbivorous land and marine iquanas of the Galápagos Islands using 16S rRNA-based pyrosequencing. ISME J. 2011:5:1461-70.

195. Godoy-Vitorino F, Ley RE, Gao Z, et al. Bacterial community in the crop of the hoatzin, a neotropical folivorous flying bird. Appl Environ Microbiol. 2008;74:5905-12.

196. Xue Z, Zhang W, Wang L, Hou R, et al. The bamboo-eating giant panda harbors a carnivore-like gut microbiota, with excessive seasonal variations. MBio. 2015;6:e00022-15. https://doi.org/10.1128/mBio.00022-15.

197. Edwards J, Johnsona C, Santos-Medellína C, Luriea E, et al. Structure, variation, and assembly of the root-associated microbiomes of rice. Proc Natl Acad Sci U S A. 2015;112:911-20.

198. Burke C, Thomas T, Lewis M, et al. Composition, uniqueness and variability of the epiphytic bacterial community of the green alga UIva australis. ISME J. 2011;5:590-600.

199. Koopman M, Fuselier DM, Hird S, et al. The carnivorous pale pitcher plant harbors distinct and time-dependent bacterial communities. Appl Environ Microbiol. 2010;76:1851-60.

200. Bai Y, Müller DB, Srinivas G, et al. Functional overlap of the Arabidopsis leaf and root microbiota. Nature. 2015;528:364-9.

201. Mendes R, Garveva P, Raaijmakers JM. The rhizosphere microbiome: significance of plant beneficial, plant pathogenic, and human pathogenic microorganisms. FEMS Microbiol Rev. 2013;37(5):634-63.

202. Vaughn D. Why run and hide when you can divide? Evidence for larval cloning and reduced larval size as an adaptive inducible defense. Mar Biol. 2010;15:1301-12

203. Hart MW. Life history evolution and comparative developmental biology of echinoderms. Evol Dev. 2002;4:62-71.

204. Sipkema D, de Caralt S, Morillo JA, Al-Soud WA, et al. Similar spongeassociated bacteria can be acquired via both vertical and horizontal transmission. Environ Microbiol. 2015;10:3807-21.

205. Hodgson S, Cates C, Hodgson J, et al. Vertical transmission of fungal endophytes is widespread in forbs. Ecol Evol. 2014;4:1199-208.

206. Kovacs M, Szendro Z, Milisits G, et al. Effect of nursing methods and feces consumption on the development of bacteroides, lactobacillus and coliform flora in the caecum of the newborn rabbits. Reprod Nutr Dev. 2006;46:205-10.

207. Baldo L, Riera JL, Tooming-Klunderud A, Albà MM, Salzburger W. Gut microbiota dynamics during dietary shift in eastern African cichlid fishes PLoS One. 2015;10(5):e0127462.

208. Colombo BM, Scalvenzi T, Benlamara S, Pollet N. Microbiota and mucosal immunity in amphibians. Front Immunol. 2015; https://doi.org/10.3389/fimmu.

209. Gilbert SF. A holobiont birth narrative: the epigenetic transmission of the human microbiome. Front Genet. 2014;5:282. https://doi.org/10.3389/fgene.

\section{Ready to submit your research? Choose BMC and benefit from:}

- fast, convenient online submission

- thorough peer review by experienced researchers in your field

- rapid publication on acceptance

- support for research data, including large and complex data types

- gold Open Access which fosters wider collaboration and increased citations

- maximum visibility for your research: over $100 \mathrm{M}$ website views per year

At BMC, research is always in progress.

Learn more biomedcentral.com/submissions 